\title{
NGHIÊN CỨU CÁC YẾU TỐ LIÊN QUAN ĐẾN RỐI LOẠN LIPID MÁU Ở BÊ̂NH NHÂN BỆNH THÂ̂N MẠN GIAI ĐOẠN CUỐI CHẠY THẬN NHÂN TẠO CHU KỲ
}

\section{TÓM TẮT}

Bệnh thận mạn là vấn đề sức khỏe toàn câu với tỷ lệ mắc bệnh ngày càng tăng. Rối loạn lipid máu là vấn đề thường gặp ở bệnh nhân bênh thận mạn, nó làm tăng nguy cơ tai biến tim mach ở bệnh nhân bênh thận mạn. Kiểm soát rối loạn lipid máu và các yếu tố liên quan đến rối loạn lipid máu là một trong những mục tiêu điều trị cho bệnh nhân bệnh thận mạn. Mục tiểu nghiên cứu: Nghiên cứu mối liển quan giữa rối loạn lipid máu với thời gian lọc máu, nguyên nhân của bềnh thân mạn, tăng huyết áp, hemoglobin máu, protein máu toàn phân và albumin huyết thanh ở bệnh nhân bệnh thận mạn giai đoạn cuối chạy thận nhân tạo chu kỳ. Phương pháp nghiên cứu: Nghiên cứu mô tả cắt ngang. Tiến hành nghiên cứu trên 60 bệnh nhân bệnh thận mạn giai đoạn cuối chạy thận nhân tạo chu kỳ tại Bênhh viện Hữu nghị Đa khoa Nghệ An. Kết quả nghiển cứu: (1) Nồng độ trung bình cholesterol máu toàn phần, TG, HDL - C, LDL - C, chỉ số TC/HDL - C, LDL/HDL - C khác nhau không có ý nghĩa thống kê giữa nhóm bệnh thận mạn chạy thận dưới 1 năm và trên 1 năm, giữa các nhóm nguyền nhân của bệnh thận mạn, giữa nhóm không tăng huyết áp và nhóm tăng huyết áp; (2) Nồng độ trung bình của triglycerid ở nhóm bệnh thận mạn có nồng đô hemoglobin < $90 \mathrm{~g} / \mathrm{l}$ cao hơn so với nhóm có nồng độ hemoglobin $\geq 90 \mathrm{~g} / \mathrm{l}$; (3) Nồng độ trung bình của cholesterol ở nhóm có nồng độ protein $<65 \mathrm{~g} / \mathrm{l}$ cao hơn so với nhóm có nồng độ protein $\geq 65 \mathrm{~g} / \mathrm{l}$; (4) Nồng độ trung bình cholesterol ở nhóm có nồng đô albumin $<35 \mathrm{~g} / \mathrm{l}$ cao hơn so với nhóm có nồng độ albumin $\geq 35 \mathrm{~g} / \mathrm{l}$ với $\mathrm{p}<0,05$.

Tư khóa: Rối loạn lipid máu, bệnh thận mạn

\section{SUMMARY}

\section{STUDY ON FACTORS RELATED TO DYSLIPIDEMIA} IN PATIENTS WITH END-STAGE RENAL DISEASE WHO ARE TREATED BY HEMODIALYSIS

Chronic kidney disease (CKD) is a global health problem, the incidence of chronic kidney disease is increasing. Dyslipidemia is a common problem in patients with CKD, it increases the risk of cardiovascular disease in patients with CKD. Manaqing dyslipidemia and the factors associated with dyslipidemia is one of the goals of treatment for patients with CKD. The aim of study: Study the relationship between dyslipidemia with: duration of dialysis, causes of CKD, hypertesion, blood

*Trường Đại học Y khoa Vinh

Chịu trách nhiệm chính: Nguyễn Văn Tuấn

Email: tuanminh1975@gmail.com

Ngày nhận bài: 23.11.2020

Ngày phản biên khoa hoc: 5.01 .2021

Ngày duyệt bài: 18.01.2021
Nguyễn Văn Tuấn*

hemoglobin, total blood protein, serum albumin in patients with ESRD who are treated by hemodialysis. Methods: A cross - sectional study on 60 patients with ESRD who are treated by hemodialysis in Nghe An General Hospital. Results: (1) Level of total cholesterol, triglyceride, $\mathrm{LDL}-\mathrm{C}$ and TC/HDL - C, $\mathrm{LDL} / \mathrm{HDL}-\mathrm{C}$ in patients with CKD who are treated by hemodialysis is not statistically different between pateints with hemodialysis less than 1 year and over 1 year, between the causes of CKD, between hypertensive and not hypertensive groups; (2) Level of triglyceride in group of patients with hemoglobin < $90 \mathrm{~g} / \mathrm{l}$ is higher than that of group of patients with hemoglobin $\geq 90 \mathrm{~g} / \mathrm{l}$; (3) Level of cholestrol in group of patients with protein $<65 \mathrm{~g} / \mathrm{l}$ is higher than that of group with protein $\geq 65 \mathrm{~g} / \mathrm{l}$; (4) Level of cholestrol in group of patients with albumin $<35 \mathrm{~g} / \mathrm{l}$ is higher than that of group with albumin $\geq 35 \mathrm{q} / \mathrm{l}$.

Key words: Dyslipidemia, CKD

\section{I. ĐẶT VẤN ĐỀ}

Bệnh thận mạn là bệnh lý suy giảm dân và không hồi phục chức năng của thận do nhiều nguyên nhân khác nhau. Đây là vấn đề sức khỏe có tính toàn câu với tân suất tăng nhanh và chi phí điều trị khổng lô. Bệnh thận mạn giai đoạn cuối đòi hỏi điêu trị thay thế thận (lọc màng bụng, thận nhân tạo chu kỳ, ghép thận), mà thận nhân tạo chu kỳ là phương pháp hiện nay được áp dụng rộng rãi.

Rối loạn lipid máu là một yếu tố nguy cơ chính của bệnh tim mạch do xơ vữa động mạch đồng thời cững là một biến chứng làm tiến triển nặng hơn bệnh thận mạn [1]. Rối loạn lipid máu ở bệnh nhân bệnh thận mạn đã được nghiên cứu bởi nhiêu tác giả trển thế giới. Ở nước ta nói chung, tỉnh Nghệ An nói riêng vấn đề này gân đây cũng được các tác giả quan tâm hơn, nhưng số lượng công trình nghiên cứu còn khiêm tốn.

Xuất phát từ nhu câu đó chúng tôi tiến hành thực hiện nghiên cứu đề tài: "Nghiên cứu các yếu tố liên quan đến rôi loạn lipid máu ở bênh nhân bệnh thận mạn giai đoạn cuôi chạy thận nhân tạo chu $k \dot{y}$ ".

\section{II. ĐỐI TƯợNG VÀ PHƯƠNG PHÁP NGHIÊN CỨU \\ 2.1. Đối tượng nghiên cứu \\ - Nhóm bệnh thận mạn: \\ + Gồm 60 bệnh nhân bệnh thận mạn giai} đoạn cuối do viêm câu thận mạn và viêm thận bể thận mạn chạy thận nhẩn tạo chu kỳ tại khoa Nội thận - thận nhân tạo, Bệnh viện hữu nghị đa 
khoa Nghệ An.

+ Hiện tại chưa điều trị bằng các thuốc có ảnh hưởng đến các biến số chính của nghiên cứu như albumin máu, các thành phần lipid máu.

- Nhóm chứng: gồm 30 người khỏe mạnh có tuổi, giới và phân bố tương ứng với nhóm bệnh.

\subsection{Phương pháp nghiên cứu}

- Thiết kế nghiên cứu: Nghiên cứu mô tả cắt ngang.

- Địa điểm nghiên cứu: Khoa nội thận - thận nhân tạo, Bệnh viện hữu nghị Đa khoa Nghệ An.

- Các bước tiến hành nghiên cứu

+ Khám lâm sàng

+ Tiến hành các xét nghiệm cận lâm sàng để khảo sát các rôi loạn lipid.

+ Định lượng TC, TG, HDL - C, LDL - C bằng phương pháp so màu enzym trên máy sinh hóa COBAS 6000.

+ Lập hồ sơ bệnh án theo mẫu nghiên cứu.

+ Đánh giá rối loạn lipid máu theo Hội Tim mạch Việt Nam 2008.

- Phương pháp xử lý số liệu: Xử lý số liệu bằng phần mềm SPSS 20.0

III. KẾT QUẢ NGHIÊN CứU

3.1. Đặc điểm chung của đối tượng nghiên cứu

Bảng 1. Phân bố theo đô tuổi của đôí tượng nghiên cứu

\begin{tabular}{|c|c|c|c|c|c|}
\hline \multirow{2}{*}{$\begin{array}{l}\text { Nhóm } \\
\text { tuổi }\end{array}$} & \multicolumn{2}{|c|}{ Nhóm bệnh } & \multicolumn{2}{|c|}{ Nhóm chứng } & $\mathbf{p}$ \\
\hline & $\mathbf{n}$ & $\%$ & $\mathbf{n}$ & $\%$ & \multirow{6}{*}{0,679} \\
\hline$<40$ & 21 & 35 & 10 & 33,3 & \\
\hline $40-59$ & 28 & 46,7 & 15 & 50 & \\
\hline$\geq 60$ & 11 & 18,3 & 5 & 16,7 & \\
\hline Trung & \multicolumn{2}{|c|}{$45,88 \pm 13,23$} & \multicolumn{2}{|c|}{$44,70 \pm 11,71$} & \\
\hline $\begin{array}{l}\text { Tống } \\
\text { cộng }\end{array}$ & 60 & 100 & 30 & 100 & \\
\hline
\end{tabular}

Nhân xét: Tuối trung bình của nhóm bênh và nhóm chứng là tương đương nhau $(p>0,05)$.

Bảng 2. Đặc điểm huyết áp của đôi tượng nghiên cứlu

\begin{tabular}{|c|c|c|}
\hline Phân độ THA & $\mathbf{n}$ & $\mathbf{\%}$ \\
\hline HA bình thương & 11 & 18,3 \\
\hline THA độ 1 & 34 & 56,7 \\
\hline THA độ 2 & 12 & 20 \\
\hline THA độ 3 & 3 & 5 \\
\hline Tống & $\mathbf{6 0}$ & $\mathbf{1 0 0}$ \\
\hline
\end{tabular}

Nhận xét: Tỷ lệ bệnh nhân tăng huyết áp là $81,7 \%$, trong đó THA độ 1 chiếm $56,7 \%$, độ 2 chiếm $20 \%$ còn THA độ 3 chiếm $5 \%$.

Bảng 3. Chỉ số cận lâm sàng của nhóm đôîi tượng nghiên cứu

\begin{tabular}{|c|c|c|c|}
\hline Chỉ số & $\begin{array}{c}\text { Nhóm beênh } \\
(n=60)\end{array}$ & $\begin{array}{c}\text { Nhómchứng } \\
(n=30)\end{array}$ & p \\
\hline Hồng cầu(T/L) & $3,32 \pm 0,66$ & $4,41 \pm 0,56$ & 0,000 \\
\hline
\end{tabular}

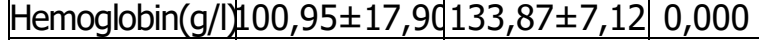

\begin{tabular}{lllll}
\hline Protein máu(g/l) $70,08 \pm 7,84$ & $74,87 \pm 5,20$ & 0,003 \\
\hline
\end{tabular}

$\begin{array}{llll}\text { Albumin máu(g/l) 39,05 } 16,55 & 43,60 \pm 3,57 & 0,000\end{array}$

Nhận xét: Số lượng hồng câu, nồng độ hemoglobin máu, protein và albumin máu thấp hơn có ý nghĩa so với nhóm chứng $(p<0,05)$.

3.2. Các yếu tố liên quan đến rối loạn lipid máu ở bệnh nhân bệnh thận mạn giai đoạn cuối chạy thận nhân tạo chu kỳ

Bảng 4. Nồng độ trung binh lipid máu theo thời gian loc máu

\begin{tabular}{|c|c|c|c|}
\hline \multirow{2}{*}{$\begin{array}{c}\text { Chỉ số } \\
\text { lipid máu }\end{array}$} & \multicolumn{2}{|c|}{$\begin{array}{c}\text { Nhóm bệnh thận } \\
\text { mạn theo thời gian } \\
\text { chậy thận nhân tặo }\end{array}$} & \multirow{2}{*}{ p } \\
\cline { 2 - 3 } & $\leq 1$ năm & $>1$ năm & \\
\hline Cholesterol & $4,54 \pm 0,63$ & $4,47 \pm 0,65$ & 0,732 \\
\hline Triglycerid & $1,57 \pm 0,68$ & $1,79 \pm 0,48$ & 0,198 \\
\hline $\mathrm{HDL}-\mathrm{C}$ & $0,89 \pm 0,25$ & $0,99 \pm 0,28$ & 0,261 \\
\hline $\mathrm{LDL}-\mathrm{C}$ & $2,59 \pm 0,63$ & $2,61 \pm 0,57$ & 0,916 \\
\hline $\mathrm{TC} / \mathrm{HDL}-\mathrm{C}$ & $5,41 \pm 1,49$ & $4,61 \pm 1,21$ & 0.056 \\
\hline $\mathrm{LDL} / \mathrm{HDL}-\mathrm{C}$ & $3,03 \pm 0,84$ & $2,78 \pm 0,94$ & 0,404 \\
\hline
\end{tabular}

Nhận xét: Nồng độ trung bình TC, TG, HDL C, LDL - C, chỉ số TC/ HDL - C và LDL /HDL - C khác biêt không có ý nghĩa thống kê giữa bệnh nhân bệnh thận mạn TNT dưới 1 năm và nhóm bệnh thận mạn TNT trên 1 năm.

Bảng 5. Nồng độ trung binh lipid máu theo nguyên nhân

\begin{tabular}{|c|c|c|c|}
\hline \multirow{2}{*}{$\begin{array}{c}\text { Chỉ số } \\
\text { lipid máu }\end{array}$} & \multicolumn{2}{|c|}{$\begin{array}{l}\text { Nhóm bệnh thận mận } \\
\text { theo nguyên nhân }\end{array}$} & \multirow[b]{2}{*}{$\mathbf{p}$} \\
\hline & $\begin{array}{l}\text { Viêm câu thận } \\
\text { mạn }(n=25)\end{array}$ & $\begin{array}{c}\text { Viêm thân bế } \\
\text { thâan mạn } \\
(\mathrm{n}=35)\end{array}$ & \\
\hline Cholesterol & $4,52 \pm 0,81$ & $4,46 \pm 0,50$ & 0,753 \\
\hline Triglycerid & $1,76 \pm 0,51$ & $1,74 \pm 0,55$ & 0.902 \\
\hline $\mathrm{HDL}-\mathrm{C}$ & $0,93 \pm 0,256$ & $1,01 \pm 0,29$ & 0,281 \\
\hline $\mathrm{HDL}-\mathrm{C}$ & $2,75 \pm 0,61$ & $2,51 \pm 0,53$ & 0,104 \\
\hline $\mathrm{TC} / \mathrm{HDL}-\mathrm{C}$ & $4,79 \pm 1,36$ & $4,77 \pm 1,26$ & 0,953 \\
\hline LDL/HDL-C & $3,05 \pm 1,01$ & $2,67 \pm 0,86$ & 0,122 \\
\hline
\end{tabular}

Nhân xét: Nồng độ trung bình các thành phần lipid máu khác nhau không có ý nghĩa thống kê giữa 2 nhóm nguyên nhân.

Bảng 6. Nồng độ trung bình lipid máu theo huyêt áp

\begin{tabular}{|c|c|c|c|}
\hline \multirow{2}{*}{$\begin{array}{c}\text { Chi số lipid } \\
\text { máu }\end{array}$} & $\begin{array}{c}\text { Nhóm nệnh nhân theo } \\
\text { tinh trạng HA }\end{array}$ & \multirow{2}{*}{ p } \\
\cline { 2 - 3 } & $\begin{array}{c}\text { Nhóm không } \\
\text { THA }(\mathrm{n}=11)\end{array}$ & $\begin{array}{c}\text { Nhóm THA } \\
(\mathrm{n}=49)\end{array}$ & \\
\hline Cholesterol & $4,38 \pm 0,64$ & $4,51 \pm 0,65$ & 0,554 \\
\hline Triglycerid & $1,76 \pm 0,66$ & $1,75 \pm 0,51$ & 0,935 \\
\hline HDL - C & $0,84 \pm 0,23$ & $1,00 \pm 0,28$ & 0,830 \\
\hline LDL - C & $2,41 \pm 0,37$ & $2,67 \pm 0,60$ & 0,192 \\
\hline TC/HDL - C & $5,04 \pm 1,53$ & $4,72 \pm 1,24$ & 0,465 \\
\hline LDL/HDL-C & $3,00 \pm 0,83$ & $2,79 \pm 0,97$ & 0,508 \\
\hline
\end{tabular}

Nhận xét: Nồng độ trung bình các thành 
phần TC, TG, HDL - C, LDL - C , chỉ số TC/HDL C, LDL/ HDL - C có sự khác biệt không có ý nghĩa thống kê $(p>0,05)$ giữa nhóm bệnh nhân tăng huyết áp và không tăng huyết áp.

Bảng 7. Nồng độ trung bình lipid máu theo nồng đồ hemoglobin

\begin{tabular}{|c|c|c|c|}
\hline \multirow{2}{*}{$\begin{array}{c}\text { Chỉ số lipid } \\
\text { máu }\end{array}$} & \multicolumn{2}{|c|}{$\begin{array}{c}\text { Nhóm bếnh nhân theo } \\
\text { nông độ̂ hemoglobin } \\
\text { máu }\end{array}$} & \multirow{2}{*}{ p } \\
\cline { 2 - 3 } & $\begin{array}{c}\mathrm{Hb}<90 \mathrm{~g} / \mathrm{l} \\
(\mathrm{n}=35)\end{array}$ & $\begin{array}{c}\mathrm{Hb} \geq 90 \mathrm{~g} / \mathrm{l} \\
(\mathrm{n}=25)\end{array}$ & \\
\hline $\begin{array}{c}\text { Cholesterol } \\
\text { (mmol/l) }\end{array}$ & $4,53 \pm 0,67$ & $4,43 \pm 0,64$ & 0,571 \\
\hline $\begin{array}{c}\text { Triglycerid } \\
\text { (mmol/l) }\end{array}$ & $1,88 \pm 0,64$ & $1,59 \pm 0,36$ & 0,032 \\
\hline $\begin{array}{c}\mathrm{HDL}-\mathrm{C} \\
\text { (mmol/l) }\end{array}$ & $0,97 \pm 0,28$ & $0,98 \pm 0,28$ & 0,945 \\
\hline $\begin{array}{c}\mathrm{LDL}-\mathrm{C} \\
\text { (mmol/l) }\end{array}$ & $2,65 \pm 0,60$ & $2,56 \pm 0,55$ & 0,523 \\
\hline TC/HDL - C & $4,74 \pm 1,48$ & $4,82 \pm 1,04$ & 0,819 \\
\hline $\mathrm{LDL} / \mathrm{HDL}-\mathrm{C}$ & $2,86 \pm 1,00$ & $2,80 \pm 0,88$ & 0,833 \\
\hline
\end{tabular}

Nhận xét: Nồng độ trung bình cholesterol, triglycerid, LDL-C, chỉ số LDL/HDL-C ở nhóm bệnh thận mạn có nồng độ $\mathrm{Hb}<90 \mathrm{~g} / \mathrm{l}$ cao hơn so với nhóm có nồng độ $\mathrm{Hb} \geq 90 \mathrm{~g} / \mathrm{l}$, nhưng chỉ có triglycerid cao hơn có ý nghĩa thống kê $(\mathrm{p}<$ $0,05)$. Nồng độ $\mathrm{HDL}-\mathrm{C}$, chỉ số $\mathrm{TC} / \mathrm{HDL}-\mathrm{C}$ thấp hơn không có ý nghĩa thống kê giữa nhóm $\mathrm{Hb}<$ $90 \mathrm{~g} / \mathrm{l}$ và $\mathrm{Hb} \geq 90 \mathrm{~g} / \mathrm{l}$.

Bảng 8. Nồng độ trung bình lipid máu theo nồng độ proteîn máu

\begin{tabular}{|c|c|c|c|}
\hline \multirow{2}{*}{$\begin{array}{l}\text { Chỉ số lipid } \\
\text { máu }\end{array}$} & \multicolumn{2}{|c|}{$\begin{array}{l}\text { Nhóm bệnh nhân theo } \\
\text { nông độ protein máu }\end{array}$} & \multirow{2}{*}{ p } \\
\hline & $\begin{array}{l}\text { Protein<65 } \\
\mathrm{g} / \mathrm{I}(\mathrm{n}=12)\end{array}$ & $\begin{array}{c}\text { Protein } \geq \\
65 \mathrm{~g} / \mathrm{l}(\mathrm{n}=48)\end{array}$ & \\
\hline $\begin{array}{l}\text { Cholesterol } \\
(\mathrm{mmol} / \mathrm{l})\end{array}$ & $4,86 \pm 0,41$ & $4,40 \pm 0,66$ & 0,022 \\
\hline $\begin{array}{l}\text { Triglycerid } \\
(\mathrm{mmol} / \mathrm{l})\end{array}$ & $1,77 \pm 0,66$ & $1,75 \pm 0,50$ & 0,829 \\
\hline $\begin{array}{l}\mathrm{HDL}-\mathrm{C} \\
(\mathrm{mmol} / \mathrm{l})\end{array}$ & $0,99 \pm 0,30$ & $0,97 \pm 0,27$ & 0,881 \\
\hline $\begin{array}{l}\mathrm{LDL}-\mathrm{C} \\
(\mathrm{mmol} / \mathrm{l})\end{array}$ & $2,73 \pm 0,59$ & $2,58 \pm 0,57$ & 0,437 \\
\hline $\mathrm{TC} / \mathrm{HDL}-\mathrm{C}$ & $4,96 \pm$ & $4,73 \pm 1,21$ & 0,586 \\
\hline LDL/HDLC & $3,08 \pm 1,32$ & $2,77 \pm 0,83$ & 0,308 \\
\hline
\end{tabular}

Nhận xét: Nồng độ trung bình cholesterol, triglycerid, $\mathrm{LDL}-\mathrm{C}, \mathrm{HDL}-\mathrm{C}$ và chỉ số $\mathrm{TC} / \mathrm{HDL}-\mathrm{C}$, LDL/HDL - C ở nhóm bệnh thận man protid máu $<65 \mathrm{~g} / \mathrm{l}$ cao hơn so với nhóm bệnh nhân có protid $\geq 65 \mathrm{~g} / \mathrm{l}$, nhưng chỉ có cholesterol cao hơn có ý nghĩa thống kê $(p<0,05)$.

Bảng 9. Nồng độ trung bình lipid máu theo albumin huyêt thanh Chỉ số lipid Nhóm bênh nhân theo máu

\begin{tabular}{|c|c|c|c|}
\hline & $\begin{array}{c}\text { Albumin } \\
<35 \mathrm{~g} / \mathrm{l} \\
(\mathrm{n}=28)\end{array}$ & $\begin{array}{c}\text { Albumin } \\
\geq 35 \mathrm{~g} / \mathrm{l} \\
(\mathrm{n}=32)\end{array}$ & \\
\hline $\begin{array}{c}\text { Cholesterol } \\
(\mathrm{mmol} / \mathrm{l})\end{array}$ & $\begin{array}{c}4,77 \pm \\
0,52\end{array}$ & $4,34 \pm 0,65$ & 0,014 \\
\hline $\begin{array}{c}\text { Triglycerid } \\
(\mathrm{mmol} / \mathrm{l})\end{array}$ & $\begin{array}{c}1,58 \pm \\
1,51\end{array}$ & $1,83 \pm 0,53$ & 0,082 \\
\hline $\begin{array}{c}\mathrm{HDL}-\mathrm{C} \\
(\mathrm{mmol} / \mathrm{l})\end{array}$ & $\begin{array}{c}1,04 \pm \\
0,26\end{array}$ & $0,94 \pm 0,28$ & 0,196 \\
\hline $\begin{array}{c}\mathrm{LDL}-\mathrm{C} \\
(\mathrm{mmol} / \mathrm{l})\end{array}$ & $\begin{array}{c}2,67 \pm \\
0,52\end{array}$ & $2,58 \pm 0,61$ & 0,555 \\
\hline $\mathrm{TC} / \mathrm{HDL}-\mathrm{C}$ & $4,71 \pm 1,36$ & $4,81 \pm 1,27$ & 0,775 \\
\hline $\mathrm{LDL} / \mathrm{HDL}-\mathrm{C}$ & $2,74 \pm 0,90$ & $2,88 \pm 0,97$ & 0,575 \\
\hline
\end{tabular}

Nhận xét: Nồng độ trung bình cholesterol, HDL - C ở nhóm bềnh thân mạn có albumin < $35 \mathrm{~g} / \mathrm{l}$ cao hơn so với nhóm bệnh thận mạn có albumin $\geq 35 \mathrm{~g} / \mathrm{l}$, nhưng chỉ có cholesterol cao hơn có ý nghĩa thống kê $(p<0,05)$. Nồng độ trung bình triglycerid, các chỉ số TC/HDL - C, LDL/HDL - C ở nhóm bệnh thân man có albumin $<35 \mathrm{~g} / \mathrm{l}$ thấp hơn so với nhóm bểnh thân man có albumin $\geq 35 \mathrm{~g} / \mathrm{l}$ nhưng không có ý nghĩa thống kê $(p>0,05)$.

\section{BÀN LUÂN}

4.1. Đặc điểm chung của đối tượng nghiên cứu. Độ tuổi trung bình trong nghiên cứu của chúng tôi là $45,88 \pm 13.23$, tuổi thấp nhất là 22 tuổi và tuổi cao nhất là 68 tuổi. Đô tuổi trung bình trong nhóm chứng là 44,70 \pm 11,71 tuổi, giữa các lớp tuổi của nhóm nghiên cứu và nhóm chứng không có sự khác biệt đáng kể $(p>0,05)$, điều này cho phép khi so sánh kết quả về rối loạn lipid máu giữa hai nhóm là hợp lý. So sánh với những nghiên cứu khác về suy thâan man trong nước trước đây không có nhiều khác biệt. Theo tác giả Võ Tam và cộng sự, độ tuổi trung bình của suy thận mạn là 45,45 \pm 13,8 tuổi [3]. Kết quả này cững tương tự nghiên cứu của tác giả Nguyễn Thị Phòng tai Bệnh viện Đại học $Y$ dược Huế (2005), độ tuổi trung bình của bệnh nhân suy thận mạn chạy thận nhân tạo chu kỳ là $41 \pm 14,54$ tuổi [2].

Tăng huyết áp là một trong những triệu chứng và biến chứng thường gặp trong bênh thận mạn. Trong nghiên cứu của chúng tôi tỷ lệ THA ở bệnh nhân bệnh thận mạn là $81,7 \%$ trên 60 đối tượng. Mức độ THA chủ yếu là độ 1 chiếm $56,7 \%$, độ 2 chiếm $20 \%$, độ 3 chiếm $5 \%$ và 18,3\% đối tượng không THA. Sự khác biệt giữa các mức độ THA có ý nghĩa thống kê. Kết quả này phù hợp với những nghiên cứu trước đây. Theo Đinh Thị Kim Dung (2003) tỷ lệ THA ở nhóm suy thân mạn chay thân nhân tạo chu kỳ là $86,7 \%$ [1],còn theo Nguyễn Thị Phòng tỷ lệ 
này là $100 \%$ [2].

Thiếu máu xuất hiện sớm trong suy thận mạn và tăng dần khi chức năng thận bị suy giảm. Kết quả nghiên cứu của chúng tôi cho thấy tỷ lệ thiếu máu rất cao là $96,7 \%$ biểu hiện cả về lâm sàng và xét nghiệm. Số lượng hồng cầu $(3,32 \pm$ $0,66 \mathrm{~T} / \mathrm{L})$ và nồng độ hemoglobin $(100,95 \pm$ $17,90)$ giảm thấp so với giá trị bình thường và có ý nghĩa thống kê $(p<0,05)$. Nghiên cứu của Huỳnh Trinh Trí về tình hình thiếu máu ở bệnh nhân suy thận mạn đang lọc máu định kỳ tại bệnh viện Chợ Rẫy ghi nhận $67,6 \% \mathrm{Hb}<10 \mathrm{~g} / \mathrm{dL}$, tỷ lệ $\mathrm{Hb}>11 \mathrm{~g} / \mathrm{dL}$ chỉ có $12,8 \%$, nồng độ $\mathrm{Hb}$ trung bình là $8,99 \pm 1,85 \mathrm{~g} / \mathrm{dL}$ [7].

Trong nghiên cứu của chúng tôi, số lượng hồng cầu $(3,32 \pm 0,66 \mathrm{~T} / \mathrm{I})$ và nồng độ hemoglobin máu $(100,95 \pm 17,9 \mathrm{~g} / \mathrm{l})$ ở bệnh nhẩn bệnh thận mạn TNT thấp hơn có ý nghĩa so với nhóm chứng $(\mathrm{p}=0,001)$. Nồng độ trung bình protein máu toàn phần $(70,08 \pm 7,84 \mathrm{~g} / \mathrm{l})$, albumin huyết thanh $(39,05 \pm 6,55 \mathrm{~g} / \mathrm{l})$ ở bệnh nhân bệnh thận mạn TNT thấp hơn có ý nghĩa so với nhóm chứng $(p<0,05)$. Kết quả nghiên cứu của chúng tôi phù hợp với nghiên cứu của Nguyễn Thị Phòng [2], Đinh Thị Kim Dung [1].

4.2. Các yếu tố liên quan đến rối loạn lipid máu ở bệnh nhân bệnh thận mạn giai đoạn cuối chạy thận nhân tạo chu kỳ. Nồng độ trung bình các thành phần lipid máu như: cholesterol, TG, HDL - C, LDL - C,TC/HDL - C, LDL/HDL - C khác biệt giữa 2 nhóm thời gian lọc máu dưới 1 năm và trên 1 năm nhưng không có ý nghĩa thống kê $(p>0,05)$. Kết quả nghiên cứu của chúng tôi cũng tương tự như nhận định của tác giả Huỳnh Văn Dũng khi nghiên cứu rối loạn lipid máu ở bệnh nhân suy thận mạn chạy thận nhân tạo chu kỳ. Theo tác giả Huỳnh Văn Dũng thì các thành phần $L D L-C, H D L-C$, chỉ số

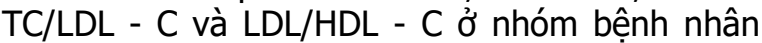
chạy thận nhân tạo trên 1 năm khác nhau không có ý nghĩa so với nhóm bệnh nhân có thời gian chạy thận nhân tạo dưới 1 năm.

Nồng độ trung bình các thành phần lipid máu khác nhau không có ý nghĩa thống kê giữa hai nhóm nguyên nhân viêm cầu thận và viêm thận bể thận mạn. Kết quả này tương tự như nghiên cứu của Nguyễn Thị Phòng [2]. Trong nghiên cứu này, nồng độ trung bình lipid máu khác nhau không có ý nghĩa thống kê giữa hai nhóm tăng huyết áp và không tăng huyết áp, phù hợp với nhận định trong nghiên cứu của Đinh Thị Kim Dung[1].

Trong nghiên cứu của chúng tôi, nồng độ cholesterol máu ở nhóm bệnh nhân có nồng độ hemoglobin < $90 \mathrm{~g} / \mathrm{l}$ thấp hơn không có ý nghĩa thống kê so với nhóm bệnh nhân có nồng độ hemoglobin $\geq 90 \mathrm{~g} / \mathrm{l}(p>0,05)$. Nồng độ cholesterol máu ở nhóm bệnh nhân có nồng độ protid máu $<65 \mathrm{~g} / \mathrm{l}$ cao hớn có ý nghĩa thống kê so với nhóm bệnh nhân có nồng độ protid máu $\geq 65 \mathrm{~g} / \mathrm{l}$ $(p<0,05)$. Điều này cho thấy ở bệnh nhân chạy thận nhân tạo nếu nồng độ protein máu càng thấp thì chỉ số cholesterol máu sẽ càng cao. Nồng độ cholesterol máu ở nhóm bệnh nhân có nồng độ albumin máu < 35g/l cao hơn có ý nghĩa thống kê so với nhóm bệnh nhân có nồng độ albumin máu $\geq 35 \mathrm{~g} / \mathrm{l}(\mathrm{p}<0,05)$. Điều này cho thấy ở bệnh nhân chạy thận nhân tạo nếu nồng độ albumin máu càng thấp thì chỉ số cholesterol máu sẽ càng cao.

Nồng độ triglycerid máu ở nhóm bênh nhân có nồng độ hemoglobin < 90g/l cao hơn có ý nghĩa thống kê so với nhóm bệnh nhân có nồng độ Hemoglobin $\geq 90 \mathrm{~g} / \mathrm{l}(\mathrm{p}<0,05)$. Điều này cho thấy ở bệnh nhân bệnh thận mạn chạy thận nhân tạo nếu nồng độ hemoglobin máu càng thấp thì chỉ số triglycerid máu sẽ càng cao. Nhận định này phù hợp với nghiên cứu của tác giả Huỳnh Văn Dũng, triglycerid có mối tương quan nghịch với hemoglobin. Nồng độ triglycerid máu ở nhóm bệnh nhân có nồng độ protid máu < $65 \mathrm{~g} / \mathrm{l}$ cao hơn so với nhóm bệnh nhân có nồng độ protid máu $\geq 65 \mathrm{~g} / \mathrm{l}$ nhưng không có ý nghĩa thống kê $(p<0,05)$. Nồng độ triglycerid máu ở nhóm bệnh nhân có nồng độ albumin máu < $35 \mathrm{~g} / \mathrm{l}$ thấp hơn so với nhóm bệnh nhân có nồng độ albumin máu $\geq 35 \mathrm{~g} / \mathrm{l}$ nhưng không có ý nghĩa thống kê $(p>0,05)$. Như vậy trong nghiên cứu này, TG không bị ảnh hưởng bởi protein máu toàn phần và albumin huyết thanh của bệnh nhân.

Nồng độ trung bình HDL - C khác biệt không có ý nghĩa thống kê giữa các nhóm $(p>0,05)$. Nồng độ trung bình LDL - $C$ khác biệt không có ý nghĩa thống kê giữa các nhóm $(p>0,05)$. Theo tác giả Huỳnh Văn Dũng, LDL - C không tương quan với hemoglobin máu và protein máu toàn phần.

\section{KẾT LUÂ̂N}

- Nồng độ trung bình của triglycerid ở nhóm bệnh thận mạn có nồng độ hemoglobin $<90 \mathrm{~g} / \mathrm{l}$ cao hơn so với nhóm có nồng độ hemoglobin $\geq 90 \mathrm{~g} / \mathrm{l}$.

- Nồng độ trung bình của cholesterol ở nhóm có nồng độ protein $<65 \mathrm{~g} / \mathrm{l}$ cao hơn so với nhóm có nồng độ protein $\geq 65 \mathrm{~g} / \mathrm{l}$.

- Nồng độ trung bình cholesterol ở nhóm có nồng độ albumin $<35 \mathrm{~g} / \mathrm{l}$ cao hơn so với nhóm có nồng độ albumin $\geq 35 \mathrm{~g} / \mathrm{l}$. 


\section{TÀI LIÊU THAM KHẢO}

1. Đinh Thị Kim Dung (2003), "Nghiên cứu rối loan Lipoprotein huyết thanh ở bệnh nhân suy thận mạn" ${ }^{\prime}$ Luận án tiến sĩ.

2. Nguyến Thị Phòng (2007), "Nghiên cứu rối loạn lipid máu ở bệnh nhân suy thân mạn giai đoạn III - IV". Luânn án chuyên khoa cấp 2, Trường đại học y dước Huế

3. Võ Tam và cộng sự (2011), Khảo sát rối loạn lipid máu ở bênh nhẩn suy thân giai đoan cuối lọc màng bụng", Trường đại học y dược Huể.

4. Ivana Mikolasevic, Marta Zutelija, Vojko mavrinac (2017), Dyslipidemia in patients with chronic kidney disease: etiology and management, Int J Nephrol Renovasc Dis, 10; 35-45.

5. KDIGO (2012), KDIGO 2012 Clinical practice guideline for the Evaluation and management of chronic kidney disease, Kidney International supplements.

6. Joana Mesquita, Ana Valera (2010), Dyslipidemia in renal disease: Causes, consequences and treatment, Endocinologia $Y$ Nutricion, 57(9): 440-448.

7. Sarnak MJ, Levey AS, Schoolwerth AC (2003), Kidney disease as a risk factor for development of cardiovascular disease, Hypertesion, 42(5): 1050-1065.

\section{ĐÁNH GIÁ KẾT QUẢ PHẪU THUÂTT CỦA UNG THƯ ỐNG TIÊU HÓA KHÔNG THUỘC BIỂU MÔ TẠI BÊ̂NH VIỆN HỮU NGHỊ VIỆT ĐỨC TRONG 10 NĂM}

\section{TÓM TẮT}

Mục tiêu: Đánh giá kết quả điều trị phẫu thuât của ung thư ống tiếu hóa không thuốc biểu mố. Phương pháp: Nghiên cứu mô tả hồi cứu. Kết quả: Thời gian nằm viện trung bình 10,3 ngày, tỷ lệ biến chứng sớm $8.3 \%$. Theo dõi $81,9 \%$ bệnh nhân: 361 bệnh nhân còn sống $(78,5 \%), 99$ bệnh nhân đã chết $(21,5 \%)$, thời gian sống sau mổ trung bình là 36,9 tháng. Tî lệ bệnh nhân sống sau mổ 1 năm, 3 năm và 5 năm tướng ứng 78,5\%,43,5\%, 22,4\%. Trong các loại tổn thương, u GIST khả năng sống sau mổ cao hởn so với u lympho. Có 87 bệnh nhân có điều trị bổ trợ sau mổ (chủ yếu là u lympho và u GIST) có thời gian sống sau mổ trung bình cao hơn so với nhóm không điểu trị bổ trợ. Kết luâan: Mặc dù chiếm tỷ lệ thấp hơn nhiều so ung thư biểu mô, nhưng các u này cũng có những biến chứng nặng mang tính chất cấp cứu có thể dẫn đến tử vong, do vậy việc đánh giá kết quả sau mổ là rất quan trọng để có cách thức điều trị và tiên lượng cho bệnh nhẩn.

Tư khóa: U không thuộc biểu mô ống tiêu hóa, đánh giá sau mổ, thời gian sống sau mổ

\section{SUMMARY \\ EVALUATE THE SURGERY RESULTS OF NON- EPITHELIAL CANCER OF GASTROINTESTINAL TRACT OPERATED AT VIET DUC UNIVERSITY HOSPITAL IN 10 YEAR}

Objective: Evaluate the surgery results of nonepithelial cancer of gastrointestinal tract (GI). Methods: retrospective study. Results: The average hospital stay was 10.3 days, the rate of early

${ }^{1}$ Bệnh viện Hữu nghi Việt Đức

Chị trách nhiêm chính: Phạm Gia Anh

Email: phamgiaanh@gmail.com

Ngày nhận bài: 19.11.2020

Ngày phản biện khoa học: 11.01.2021

Ngày duyệt bài: 20.01.2021
Phạm Gia Anh', Trịnh Hồng Sơn'

complications was $8.3 \%$. Follow up $81.9 \%$ of patients: 361 patients were still alive $(78.5 \%), 99$ patients died $(21.5 \%)$, the average survival time post surgery was 36.9 months. The rates of patients living after 1 year, 3 years and 5 years after surgery are $78.5 \%, 43.5 \%$, $22.4 \%$ respectively. Among the types of lesions, GIST tumors have higher postoperative survival than lymphoma. There were 87 patients with postoperative adjuvant treatment (mainly lymphoma and GIST tumors) had a higher mean postoperative survival time compared to the group without adjuvant treatment. Conclusion: Although non-epithelial tumors's prevalence rate is lower than adenocarcinoma, it also have serious complications of an emergency that can lead to death, therefore, it is very important to evaluate the outcomes after surgery for the treatment and prognosis of the patient.

Keywords: non-epithelial gastrointestinal tract tumors, postoperative evaluation, survival time

\section{I. ĐĂT VẤN ĐỀ}

Ung thư ống tiêu hóa (ÔTH) không thuộc biểu mô bao gồm nhóm u trung mô (Digestive Mesenchymal Tumors) và u lympho của ÔTH, chiếm tỉ lệ dưới $5 \%$ toàn bộ ung thư của ÔTH, có hơn 10 loại khác nhau bao gồm nhóm chiếm tỉ lệ ít hơn có hình ảnh mô bệnh học và tiêu chuẩn chẩn đoán giống u mô mềm ở các cơ quan khác như u mõ̃, u cơ trơn, u vỏ bao thần kinh, u mạch máu, u cơ vân... và nhóm khác chiếm phần lớn không đồng nhất gọi là u mô đệm ống tiêu hoá hay u mô đệm dạ dày ruột (GIST - GastroIntestinal Stromal Tumors) và u lympho [1],[2]. Trên thế giới và tại Việt Nam cũng đã có các công trình nghiên cứu về u ÔTH không thuộc biểu mô, tuy nhiên các tác giả thường nghiên cứu môtt loại tổn thương trên môt hoặc nhiều tạng mà chưa có nghiên cứu nào một 